\title{
Features of the preparation of biological material for genome editing in cattle
}

\author{
A. S. Barkova ${ }^{1}$, V. A. Makutina ${ }^{1}$, M. V. Modorov ${ }^{1}$, A. G. Isaeva ${ }^{1}$, A. S. Krivonogova ${ }^{1}$ \\ ${ }^{1}$ Ural Federal Agrarian Scientific Research Centre - Ural Branch of the Russian Academy of Sciences, \\ Ekaterinburg, Russia \\ ๑-mail: isaeva.05@bk.ru
}

Abstract. To carry out genome editing in cattle, an effective and well-functioning system for obtaining gametes, fertilizing eggs and their cryopreservation is necessary. Aim of the work: review and research of present-day existing methods of obtaining, insemination and cryopreservation of donor material, in order to provide genome editing in cows. Methods and materials. The work is completed according to the theme No. 0532-2019-0001 "Development of complex technology of marker-based genome selection of agricultural animals" within State Order of Ministry of Education and Science of the Russian Federation. The analysis of open scientific literature on the issues of in vitro fertilization in animals, cryopreservation of oocytes and embryons, sperm preparation and methods of insemination of cows' oocytes, and cryopreservation of oocytes and embryons of animals is done. Features of the preparation of biological material of cattle for genome editing by microinjection into ooplasm are described. Results of research and duscussion. At present time there are two ways to obtain donor material from cattle: from live animals and taking ovaries after slaughtering cows. Material transportation is carried out at a temperature of $30-37^{\circ} \mathrm{C}$ depending on the distance to the laboratory and expected time period of transportation. Oocytecumulus complexes can be removed by ovarian dissection and aspiration of visible follicles. In both cases, immature eggs are predominantly obtained. Subsequent ripening is carried out in vitro using special media in a $\mathrm{CO}_{2}$ incubator. The culture medium for oocyte maturation should contain hormones that mimic the peak of LH (luteinizing hormone), which occurs in vivo during the maturation of oocytes before ovulation. To accumulate a certain number of eggs at the stage of MII, it is recommended to carry out their cryopreservation by the method of vitrification, having previously released the oocyte from the cumulus cells. After thawing, oocytes need to be incubated for $2-3$ hours $38.5^{\circ} \mathrm{C}$ in $5-6.5 \% \mathrm{CO}_{2}$ to restore the spindle. In order to make editing more effective, the introduction of genetic material is recommended to be carried out in parallel with the fertilization method "icsi". In humans, mice and rabbits, an injection of sperm into the cytoplasm is sufficient to activate the oocyte, however, in cattle, just micro-injection of the sperm is not enough and often the male pronucleus does not form. To solve the problem, various methods are used, including freezing-thawing of sperm, resulting in damage of a membrane, or addition of heparin-glutathione into the medium that increases decondensation of the sperm DNA.

Keywords: genetic modeling, in vitro maturation of oocytes, artificial insemination in cows, oocyte vitrification.

For citation: Barkova A. S., Makutina V. A., Modorov M. V., Isaeva A. G., Krivonogova A. S. Features of the preparation of biological material for genome editing in cattle // Agrarian Bulletin of the Urals. 2019. No. 12 (191). Pp. 40-44. DOI: ...

Paper submitted: 14.10.2019.

\section{Introduction}

Introduction of planned changes into cattle genome makes it possible to obtain animals with expected economic characters, such as disease resistance, necessary composition of milk, improved productivity and others [27]. For genome editing both somatic cells and gamets can be used. In the first case, genetically modified nucleus of somatic cells are introduced into an oocyte. This procedure is called somatic cell nuclear transfer. However, because of low acceptance of embryons and high rate of abortions, this technology needs a significant number of recipients. The method that is alternative to cloning is microinjection into in vitro inseminated oocyte. Using the latter method significantly increases a number of recipients' successful pregnancies and deliveries (as compared to the method of somatic cell nuclear transfer). Thus, to successfully obtain a necessary number of transgenic animals, it is possible to use less recipients [26, 28]. This work describes present-day existing methods and features of preparation of biological material of cattle for a microinjection into ooplasm.

\section{Methods}

The work is completed according to the theme No. 05322019-0001 "Development of complex technology of markerbased genome selection of agricultural animals" within State Order of Ministry of Education and Science of the Russian Federation. The analysis of public-accessed scientific literature on the issues of in vitro ferrilization in animals, cryopreservation of oocytes and embryons, sperm preparation and methods of insemination of cows' oocytes, and cryopreservation of oocytes and embryons of animals is done. Features of the preparation of biological material of cattle for genome editing by a microinjection into ooplasm are described. 


\section{Results}

Sampling and maturation of oocytes. At present there are a few ways to obtain bovine oocytes. A modern approach is the use of OPU (ovum pick up) technology, that is obtaining oocytes from follicles of alive animals, using an ultrasound prober, special nozzle and an aspirating needle. This method can be used with both mature animals and adult heifers [8]. OPU can be done both with preliminary hormonal preparation of a donor (stimulation of superovulation), as well as under the conditions of normal ovary cycle. Without exogenetic hormones, one donor can produce oocytes once in two or three weeks, with aspiration of from two to five follicles. In case of superovulation, it is possible to obtain up to more than 20 oocytes in one cycle, if donors are used once in two or more months [9]. An advantage of OPU technology is the possibility to use one donor many times, and disadvantages are high cost of necessary equipment and high demands to qualification of personnel involved in doing that procedure.

An alternative of OPU is obtaining oocytes from cows' ovarium directly after slaughtering, preferably avoiding ovarium from pregnant cows, ovarium having abnormities, such as cystous follicles ( $>20 \mathrm{~mm}$ in diameter) and ovarium carrying yellow body. It is known that level of blastulation (formation of blastocytes) is significantly lower [16].

It is possible to transfer the whole oocyte to the laboratory or do aspiration of visualized follicles and transfer them in follicular fluid with oocyte-cumulus complexes in buffered medium. Follicles of from 2 to $8 \mathrm{~mm}$ are aspirated with a $18 \mathrm{G}$ needle attached to a 5-10 $\mathrm{ml}$ syringe $[18,24]$. Transportation is done in special incubators with constant temperature 30$35{ }^{\circ} \mathrm{C}[11,24]$. According to the data obtained by L. V. Golubets and co-authors, the optimum delivery time of oocytes tissue or aspirated oocyte-cumulus complexes at temperature of $37{ }^{\circ} \mathrm{C}$ is not more than 3 hours, whereas formation of morulas/ blastocytes can be up to $27 \%$. Longer time of transportation significantly reduces level of blastulation [2].

Oocyte-cumulus complexes obtained from non-stimulated oocytes need to get matured until the stage of mature oocytes (the stage of metaphase II - M II), suitable for insemination (IVM - in vitro maturation). To achieve that, oocytecumulus complexes are cultivated for 20-24 hours in culture medium at temperature of $38,5^{\circ} \mathrm{C}, \mathrm{pH}$ of medium is about $7,3\left(5-6,5 \% \mathrm{CO}_{2}\right)$ and $5 \% \mathrm{O}_{2}$. The culture medium for maturing oocytes should have hormones that mimic peak of LH (luteinizing hormone) occuring in vivo during the period of maturation of oocytes before ovulation. There are a number of scientific works regarding optimization of medium of maturation, but nowadays the standard one is the TCM-199 medium with bicarbonate buffer with added $10 \%$ fetal calf serum, $22 \mathrm{ug} / \mathrm{ml}$ sodium pyruvate, $50 \mathrm{ug} / \mathrm{ml}$ gentamycine and $1 \mathrm{ug} /$ $\mathrm{ml} 17 \beta$-estradiol. Main modifications are caused by changes in concentration of gonadotropins introduced into culture medium. As a rule, doses of $0,5 \mathrm{ug} / \mathrm{ml} \mathrm{FSH}$ (follicle stimulating hormone) and 5-50 ug/ml HGG (human chorionic gonadotropin) or $5 \mathrm{ug} / \mathrm{ml} \mathrm{LH}$ (luteinizing hormone) are used [4, 12, 22, 24]. Methods of cultivation of donor oocytes in medium with prolactin are developed and successfully used [5, 6]

Preparation of spermatozoids. For successful insemination of an oocyte, sperm needs to undergo biochemical modi- fications (capacitation), resulting in elimination of factors blocking acrosomal activity. By natural insemination capacitation takes place in female reproductive tracts. In case of in vitro insemination, an ejaculate needs preliminary treatment, that is dissection of sperm from semenal plasma, as well as from immobile and dead spermatozoids and/or cryoprotectors (if an ejaculate was originally cryopreserved), as well as preincubation in special medium for their capacitation.

If sperm has not been cryopreserved, most spermatozoids are active and mobile, whereas in the course of cryopreservation a part of spermatozoids die that leads to mobility after thawing from 30 to $70 \%$ [21].

Treatment of sperm can be done by "swim-up" method or centrifugalization in Percoll gradient. "Swim-up" method is quite often used for migration of spermatozoids. It includes overlaying of culture medium on sperm that allows progressive motility spermatozoids to move from semenal plasma to pure fraction of medium.

Centrifugalization in Percoll gradient is also rather often used. It results in division of sperm into spermatozoids and semenal plasma by centrifugalization in discontinuous Percoll gradient (Percoll $45 \%$ and Percoll $90 \%$ ) for 5-10 minutes at 1500-3000 g and at room temperature. Sperm pellet after centrifugalization is washed by buffer fluid for 3-5 minutes at $1000 \mathrm{~g}$ [23].

Further preincubation of sperm in culture medium is necessary for capacitation. There are a few modification of protocol of sperm preincubation, such as addition of heparin in various concentration in culture medium, changing duriation of an incubation period, or addition of caffeine and/or $\mathrm{Ca}$ ionophore [10, 12, 22].

Insemination. After preincubation sperm is introduced into medium with matured oocyte-cumulus complexes. Amount of sperm added to oocyte-cumulus complexes during in vitro fertilization affects percentage of zygotes inseminated by a few spermatozoids (polyspermy). As a rule, it is enough to introduce in the medium sperm in concentration of about 1.0-9.0 $\times 10^{6}$ mobile spermatozoids/ml $[19,24]$.

In some cases, for example, in case of the use of preliminary cryopreserved oocytes, it is necessary to do fertilization using the method of intracytoplasmic a sperm injection into oocyte (ICSI).

DNA of mammals' spermatozoids is tightly packed with protamine sulfate links. After penetration into an oocyte, a spermatozoid is subjected to decondensation by means of replacing protamines of spermatozoids with histons of an oocyte that leads to decondensation of chromatine and formation of male pronucleus, which later links with female pronucleus resulting in formation of a zygote [15]. In humans, mice and rabbits, an injection of sperm into the cytoplasm is sufficient to activate the oocyte. However, in cattle, just micro-injection of the sperm is not enough and often the male pronucleus does not form.

To solve the above-mentioned issue, various kinds of methods are used, including freezing-thawing of a spermatozoid, that results in damage of a membrane, and addition of heparin-gluthatione or dithiothreitol, which facilitate decondensation of DNA of sperm [20]. 
Before doing ICSI it is necessary to remove oocyte-cumulus cells by repeated pipetting in $0,1 \%$ solution of hyaluronidase that allows to denudate an oocyte from cells of cumulus and granulosis. For an injection only oocytes at the stage of MII, which extruded the first polar body can be used.

After an injection it is possible to activate oocytes, in order to provide extrusion of the second polar body, by influence of $7 \%$ etanol for 3-5 minutes [17, 25]. However, outer activation of an oocyte can cause virginal reproduction [18].

Oocytes demonstrating extrusion of the second PB after 3-4 hours after activation are considered to be insemintated $[17,25]$.

Cryopreservation. It is possible to cryopreserve oocytes before genome editing both at the MII stage and after insemination. At present time a standard method of cryopreservation is considered to be vitrification, that is ultrafast cooling without crystallization. Originally vitrification was used for cryopreservation of mice's embryos. In the course of vitrification cells or tissues are subjected to influence of high concentration of cryoprotectors penetrating inside, which effectively dehydrate a cell before the start of cooling. Long effect of high concentrations of penetrating cryoprotectors is harmful for cells [13]. High cooling speed during vitrification is a main criteria of success that helps to avoid damage of cells because of cooling and cryoprotectors.

Oocytes showed high sensitivity to cryopreservation because of low proportion between their surface and volume that prevents motion of water and penetrating cryoprotectors through cell plasma membranes [4]. Besides, vitrification of mature oocytes at the metaphase of miosis II (MII) leads to disorganization or damage of meiotic spindle that results in chromosomal aberration. On the other hand, in immature oocytes at the stage of a germinal vesicle (GV) depolymerization of spindle does not occur, but oocytes at the GV stage are more sensitive to osmotic stress than the MII oocytes. The first successful vitrification of the MII oocytes of cows was done using the grid of electron microscope and $0.25 \mathrm{ml}$ plastic straws as a device for vitrification [18]. Since then a few more devices have been developed, each one using a special method of minimization of volume of solution for vitrification: Cryoloop, a straw with open strain, a glass capillary, Cryotop, cellulose triacetate hollow fibers [3, 25].

The issue of necessity of cumulus cells for successful vitrification of mature oocytes, is disputable. Some researchers vitrified mature oocytes of cows with a few layers of cumulus cells. Nevertheless, according to other data, availability of cumulus in mature oocytes of cows reduced survival rate after vitrification, as cumulus cells probably prevented diffusion of water and cryoprotectors [21]. The reason for incompatibility of the results can be differences in vitrification protocols, and the use of various cryoprotectors (ethylene glycol or mixture of ethylene glycol/dimethylsulfoxide).

Nowadays numerous vitrification protocols have been developed, whereas main difference between them regards the used cryoprotectors and their concentration. The process of vitrification starts with equilibration of oocytes/zygotes for 12-15 minutes at room temperature in the solution with low concentration of penetrating cryoprotectors, 3-4 \% ethylene glycol or 7,5\% ethylene glycol $+7,5 \%$ dimethylsulfoxide. Af- ter equilibration oocytes/zygotes are placed in the medium for vitrification, containing 30-35\% ethylene glycol with addition of $1,0 \mathrm{~mol} / \mathrm{L}$ saccharose or $15 \%$ dimethylsulfoxide $+15 \%$ ethylene glycol $+0.5 \mathrm{~mol} / \mathrm{L}$ saccharose $[14,23]$. In the vitrification medium oocytes/zygotes should stay for not more than 1.5 minutes until their placing into liquid nitrogen, including the time of putting them on the device for vitrification.

For thawing, the device for vitrification is placed in $2-5 \mathrm{ml}$ of medium containing $0.5-1 \mathrm{~mol} / \mathrm{L}$ saccharose or $0.3 \mathrm{~mol} / \mathrm{L}$ trehalosa at temperature of $37{ }^{\circ} \mathrm{C}$ for 1 minute. After that oocytes/zygotes are transferred to the medium with reduced concentration of saccharose or trehalosa for 3-5 minutes in each medium [11, 14]. Gradual changes in concentration of penetrating cryoprotectors is necessary to prevent excess increase of cell volume and cell lysis during influence of large osmotic gradients on the membrane.

After heating oocytes are incubated for 2-3 hours at temperature of $38.5^{\circ} \mathrm{C}$ in $5-6.5 \% \mathrm{CO}_{2}$ for restoring spindle.

According to the data obtained by L. Letkevich and coauthors (2015) survival rate of oocytes after vitrification in different cryoprotectors is $36.9 \%$ [7]. In the work of A. I. Gandzha and coauthors (2017) it was stated that cryopreservation of oocytes obtained from follicles and at different stages of development makes it possible to preserve more than $80 \%$ of cells, with obtaining up to $18 \%$ of cleavage stage embryons, including $5.5 \%$ up to the stage of blastocyst [1].

\section{Discussion and Conclusion}

The analysis of literature source showed that at present there are a few ways of obtaining biological material from cows that allows to choose the most suitable one to obtain oocyte-cumulus complexes. The further cultivation of oocytes is done in culture medium at temperature of $38.5^{\circ} \mathrm{C}$, $\mathrm{pH}$ of medium about $7.3\left(5-6.5 \% \mathrm{CO}_{2}\right)$ and $5 \% \mathrm{O}_{2}$. The culture medium should contain hormones that mimic the peak of LH (luteinizing hormone) in ovarian cycle. The literature gives description of a few modifications of culture media that mostly differ in concentration of gonadotropins introduced in culture medium. For insemination of mature oocytes two methods were suggested: ICSI and insemination of spermatozoids, after capacitation, in the medium with oocyte-cumulus complexes. As genome editing needs some definite amount of biomaterial, the issue of its long-term preservation arises. The most effective way of cryopreservation of oocytes is vitrification. According to a number of researches, survival rate of oocytes after vitrification is from 37 to $80 \%$.

Thus, for preparation of biological material for further genome editing of cattle by means of microinjection into an oocyte it is possible to suggest the following order of actions. At the first stage it is recommended to provide accumulation of biomaterial: aspiration of oocyte-cumulus complexes from ovary obtained after cows' slaughtering; further maturation of oocytes in special mediums; cryopreservation by method of vitrification of oocytes at the MII stage, or zygotes after insemination. The second stage includes thawing unfertilized eggs and their insemination by the ICSI method with introduction of system of editing, or thawing of zygotes and their editing by microinjections. 


\section{References}

1. Gandzha A. I., Letkevich L. L., Kuzmina T. I., Simonenko V. P., Kirillova I. V., Rakovich E. D., Kurak O. P., Zhurina N. V., Kovalchuk M. A., Glutschenko L. V., Burakova O. V. Cryoconservation and cryotolerance of oocytes of agricultural animals [Cryopreservation and cryotolerance of oocytes of agricultural animals] // Zootekhnicheskaya nauka Belarusi. 2017. No. 1 (52). Pp. 46-52. (In Russian.)

2. Golubets L. V., Deshko A. S., Starovojtova M. P., Stetskevich E. K., Otroschenko A. E., Bergel A. I. Ekstrakorporal'noye oplodotvoreniye ootsitov krupnogo rogatogo skota: metodicheskiye rekomendatsii [In vitro fertilization of oocytes of cattle: methodological recommendations]. Grodno: GSAU, 2010. 48 p. (In Russian.)

3. Kornienko E. V., Ikonopistseva M. A., Malenko G. P. Vitrifikatsiya dozrevshikh in vitro ootsitov krupnogo rogatogo skota $\mathrm{v}$ triatsetattsellyuloznykh polykh voloknakh [Vitrification of matured vitro oocytes of cattle in cellulose triacetate hollow fibers] // Dostizheniya nauki i tekhniki APK. 2018. No. 9 (32). Pp. 84-88. (In Russian.)

4. Kuzmina T. I., Helmut T., Alm H. Funktsional'naya aktivnost' mitokhondriy v nativnykh i deitrifitsirovannykh ootsitakh Bos Taurus pri sozrevanii in vitro [Capacity of mitochnondrions in native and denitrified oocytes Bos Taurus by in vitro maturation] // Genetika i razvedeniye zhivotnykh. 2018. No. 2. Pp. 67-72. (In Russian.)

5. Kuzmina T. I., Molchanov A. V., Tatarskaia D. N., Stanislavovich T. I. Modernizatsiya etapov tekhnologii ekstrakorporal'nogo sozrevaniya donorskikh ootsitov Bos Taurus [Modernization of technological stages of in vitro maturation of donor oocytes Bos Taurus] // Agrarian Scientific Journal. 2017. No. 3. Pp. 9-13. (In Russian.)

6. Kundik Yu. V., Kuzmina T. I., Pozdniakova T. E. Kul'tivirovaniye doimplantatsionnykh embrionov korov v sredakh s prolaktinom [Cultivation of preimplant embryons of cows in mediums with prolactin] // Vestnik studencheskogo nauchnogo obshchestva. 2019. Pp. 139-140. (In Russian.)

7. Letkevich L. L., Ganddzha A. I., Kuzmina T. I., Simonenko V. P., Kirillova I. V., Rakovich E. D., Kurak O. P., Zhurina N. V., Kovalchuk M. A. ZHiznesposobnost' dekonservirovannykh ootsitov korov posle vitrifikatsii fragmentov yaichnikov i ovarial'nykh follikulov s ispol'zovaniyem kombinatsii kroioprotektorov [Vital capacity of frozen-thawed oocytes of cows after vitrification of fragments of ovaries and ovarian follicles using combinations of cryoprotectors] // Zootekhnicheskaya nauka Belarusi. 2015. V. 50. No. 1. Pp. 109-117. (In Russian.)

8. Madison V., Madison L. Transplantatsiya embrionov: khorosho zabytoye staroye [Transplantation of embryons: the old ways are the best ways] // Zhivotnovodstvo Rossii. Tematicheskiy vypusk. 2018. Pp. 11-17. (In Russian.)

9. Popov D. V., Brigida A. V., Kosovtskii G. Yu. Rukovodstvo po transplantatsii embrionov krupnogo rogatogo skota [Guideline for transplantation of bovine embryons]. Moscow, 2017. 56 p. (In Russian.)

10. Patent for invention RUS 2639268 20.12.2017 Sposob kapatsitatsii kriokonservirovannykh spermatozoidov krupnogo rogatogo skota dlya rabot po in vitro oplodotvoreniyu yaytsekletok [Method of capacitation of cryopreserved sperm of cattle for in vitro insemination of oocytes] / Smetanina A. G., Tatarinova L. V., Krivokharchenko A. S., Riabykh V. P. (In Russian.)

11. Arcarons N., Morató R., Vendrell M. [et al.] Cholesterol added prior to vitrification on the cryotolerance of immature and in vitro matured bovine oocytes // PLoS One. 2017. No. 12 (9): e0184714. Published 2017. Sep 14. DOI: 10.1371/journal. pone.0184714.

12. Bakri N. M., Ibrahim S. F., Osman N. A. [et al.] Embryo apoptosis identification: Oocyte grade or cleavage stage? // Saudi J. Biol. Sci. 2016. No. 23 (1). Pp. 50-55. DOI: 10.1016/j.sjbs.2015.10.023.

13. Hwang I. S., Hoichi S. Recent progress in cryopreservation of bovine oocytes // Biomed Res Int. 2014. No. 570647. DOI: 10.1155/2014/570647.

14. Ishii T., Tomita K., Sakakibara H., Ohkura S. Embryogenesis of vitrified mature bovine oocytes is improved in the presence of multi-layered cumulus cells // The Journal of Reproduction and Development. 2018. Vol. 64,1. Pp. 95-99. DOI: 10.1262/ jrd.2017-095.

15. Jenkins T. G., Carrell D. T. Dynamic alterations in the paternal epigenetic landscape following fertilization // Front Genet. 2012. No. 3: 143 DOI: 10. 3389/fgene.2012.00143.

16. Karami S. H., Shahsavari M. H., Hajarian H., Moghaddam G. In vitro developmental competence of bovine oocytes: Effect of corpus luteum and follicle size // Iran J. Reprod. Med. 2015. No. 13 (10). Pp. 615-622.

17. Kato Y., Nagao Y. Changes in Sperm Motility and Capacitation Induce Chromosomal Aberration of the Bovine Embryo following Intracytoplasmic Sperm Injection // PLoS One. 2015. Vol. 10,6 e0129285. DOI: 10.1371/journal.pone.0129285.

18. Magata F., Tsuchiya K., Okubo H., Ideta A. Application of intracytoplasmic sperm injection to the embryo production in aged cows // The Journal of veterinary medical science. 2019. Vol. 81-1. Pp. 84-90. DOI: 10.1292/jvms.18-0284.

19. Oikawa T., Itahashi T., Numabe T. Improved embryo development in Japanese black cattle by in vitro fertilization using ovum pick-up plus intracytoplasmic sperm injection with dithiothreitol // The Journal of Reproduction and Development. 2016. No. 62 (1). Pp. 11-16. DOI: 10.1262/jrd.2015-067.

20. Oikawa T., Itahashi T., Yajima R., Numabe T. Glutathione treatment of Japanese Black bull sperm prior to intracytoplasmic sperm injection promotes embryo development // J. Reprod. Dev. 2018. No. 64 (4). Pp. 303-309. DOI: 10.1262/jrd.2018-023. 21. Ortiz-Escribano N., Smits K., Piepers S., Van den Abbeel E., Woelders H., Van Soom A. Role of cumulus cells during vitrification and fertilization of mature bovine oocytes: Effects on survival, fertilization, and blastocyst development // Theriogenology. 2016. No. 86. Pp. 635-641. DOI: 10.1016/j.theriogenology.2016.02.015. 
22. Parrish J. J. Bovine in vitro fertilization: in vitro oocyte maturation and sperm capacitation with heparin // Theriogenology. 2014. No. 81 (1). Pp. 67-73. DOI: 10.1016/j.theriogenology.2013.08.005.

23. Punyawai K., Anakkul N., Srirattana K. [et al.] Comparison of Cryotop and micro volume air cooling methods for cryopreservation of bovine matured oocytes and blastocysts // J. Reprod. Dev. 2015. No. 61 (5). Pp. 431-437. DOI: 10.1262/ jrd.2014-163.

24. Siqueira A. F. P., de Castro L. S., de Assis P. M. [et al.] Sperm traits on in vitro production (IVP) of bovine embryos: Too much of anything is good for nothing // PLoS One. 2018. No. 13 (7): e0200273. DOI: 10.1371/journal.pone.0200273.

25. Suttirojpattana T., Somfai T., Matoba S., Nagai T., Parnpai R., Geshi M. Pretreatment of bovine sperm with dithiobutylamine (DTBA) significantly improves embryo development after ICSI // J. Reprod. Dev. 2016. No. 62 (6). Pp. $577-585$. DOI: $10.1262 /$ jrd.2016-084.

26. Vajta G., Holm P., Greve T., Callesen H. Vitrification of porcine embryos using the Open Pulled Straw (OPS) method // Acta Vet. Scand. 1997. No. 38. Pp. 349-352.

27. Van Eenennaam A. L. Genetic modification of food animals // Current Opinion in Biotechnology. 2017. V. 44. Pp. $27-34$. DOI: 10.1016/j.copbio.2016.10.007.

28. Yum S. Y., Youn K. Y., Choi W. J., Jang G. Development of genome engineering technologies in cattle: from random to specific // Journal of Animal Science and Biotechnology. 2018. V. 9. DOI: 10.1186/s40104-018-0232-6.

\section{Authors'information:}

Anna S. Barkova ${ }^{1}$, doctor of veterinary sciences, senior scientific researcher, ORCID 0000-0002-2602-6810, AuthorID 610629; barkova.as@mail.ru

Valeria A. Makutina ${ }^{1}$, candidate of biological sciences, senior scientific researcher, ORCID 0000-0003-1127-2792,

AuthorID 612436

Makar V. Modorov ${ }^{1}$, candidate of biological science, senior scientific researcher, ORCID 0000-0003-1877-2378,

AuthorID 178678

Albina G. Isaeva ${ }^{1}$, doctor of veterinary sciences, associate professor, leading scientific researcher,

ORCID 0000-0001-8395-1247, AuthorID 665717: isaeva.05@bk.ru

Anna S. Krivonogova ${ }^{1}$, doctor of veterinary sciences, associate professor, leading scientific researcher,

ORCID 0000-0003-1918-3030, AuthorID 683239

${ }^{1}$ Ural Federal Agrarian Scientific Research Centre - Ural Branch of the Russian Academy of Sciences, Ekaterinburg, Russia 